\title{
Correction to: The Bildung Theory-From von Humboldt to Klafki and Beyond
}

\author{
Jesper Sjöström and Ingo Eilks
}

\section{Correction to:}

Chapter 5 in: B. Akpan and T. Kennedy (eds.),

Science Education in Theory and Practice, Springer Texts in Education, https://doi.org/10.1007/978-3-030-43620-9_5

Chapter 5, "The Bildung Theory-From von Humboldt to Klafki and Beyond" was previously published non-open access. It has now been converted to open access under a CC BY 4.0 license and the Copyright Holder is "The Author(s)". The book has also been updated with this change.

Open Access This chapter is licensed under the terms of the Creative Commons Attribution 4.0 International License (http://creativecommons.org/licenses/by/4.0/), which permits use, sharing, adaptation, distribution and reproduction in any medium or format, as long as you give appropriate credit to the original author(s) and the source, provide a link to the Creative Commons license and indicate if changes were made.

The images or other third party material in this chapter are included in the chapter's Creative Commons license, unless indicated otherwise in a credit line to the material. If material is not included in the chapter's Creative Commons license and your intended use is not permitted by statutory regulation or exceeds the permitted use, you will need to obtain permission directly from the copyright holder.

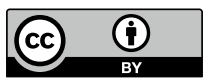

The updated version of this chapter can be found at https://doi.org/10.1007/978-3-030-43620-9_5

(C) The Author(s) 2021

B. Akpan and T. Kennedy (eds.), Science Education in Theory and Practice,

Springer Texts in Education,

https://doi.org/10.1007/978-3-030-43620-9_33 